\title{
The Effect of Rates and Service Quality Towards The Customer Satisfaction of PT Pelabuhan Indonesia III (Persero) Banjarmasin Branch
}

\author{
Mawan Budiyanto, RR Yulianti Prihatiningrum \\ Master of Management, Lambung Mangkurat University Banjarmasin \\ Email: Mawanbudi84@gmail.com
}

\begin{abstract}
ARTICLE INFO
Received

08 September 21

Revision

12 September 21

Approved

13 September 21

\section{Keywords:}

Rates;

Quality Interaction;

Physical Environment

Quality;

Outcomes Quality;

Customer satisfaction

\section{ABSTRACT}

This study aims to analyze the effect of rates (X1), interactions quality $(\mathrm{X} 2)$, physical environment quality (X3), and outcomes quality (X4) as partially independent variables on the customer satisfaction $(Y)$ as the dependent variable on users of ship guidance services at PT Pelabuhan Indonesia III (Persero) Banjarmasin Branch. Data were collected by distributing questionnaires to 115 respondents. The samples were determined based on the total sampling technique. There were 115 respondents chosen as the samples. The research site was at PT. Pelabuhan Indonesia III (Persero) Banjarmasin Branch. The unit of analysis was all customers at PT. Pelabuhan Indonesia III (Persero) Banjarmasin Branch. Measurement of variables was conducted using the Likert scale technique with a scale of weights from 1 to 5 . These were meant to analyze the effect of variable rates $(X 1)$, quality of interactions $(X 2)$, quality of physical environment $(X 3)$, and quality of results (X4) on customer satisfaction (Y) using techniques multiple linear regression statistics. The results showed that the variable rates (X1), interactions quality (X2), physical environment quality (X3), and outcomes quality (X4) has a positive and significant effect on customer satisfaction partially on PT. Indonesian Port III, Banjarmasin Branch. and outcomes quality (X4) partially had a positive and significant effect on customer satisfaction at PT. Indonesian Port III, Banjarmasin Branch. and outcomes quality (X4) partially had a positive and significant effect on customer satisfaction at PT. Indonesian Port III, Banjarmasin Branch.
\end{abstract}

\section{INTRODUCTION}

Do you know that the United States always conducts various strategic visits and cooperation of various countries in the Asia Pacific region (Gindarsah, 2014)? According to Sakti Adji (Adisasmita, 2011), one of the means to connect a producer area to a consumer place or vice versa is tool transportation. Sea transportation has a vital role for an archipelagic country like Indonesia, but the development of the
Indonesian shipping industry is relatively slow compared to the international world.

For example, in North Sumatra, to make the port's role more vital, North Sumatra is developing its industrial sector (Kusuma, Setiono, \& Poli, 2018). One of them is an effort to create effective sea connectivity in the form of ships that sail regularly and on a scheduled basis from west to east with the sea highway. (Nasional \& NASIONAL, 2015) This idea begins with maintaining and renewing ports, both nationally and internationally. (Sinaga, Mamahit, \& Yusnaldi, 2020) Although there
How To Cite:

E-Issn:

Published By:
Budiyanto, M., \& Prihatiningrum, RR. Y. (2021) The Effect of Rates and Service Quality Towards The Customer Satisfaction of PT Pelabuhan Indonesia III (Persero) Banjarmasin Branch. Journal of Social Science 2(5). https://doi.org/10.46799/jss.v2i5.223 2721-5202

Ridwan Institut 
are often obstacles in its construction, this is very useful to determine the feasibility of the construction of the marine highway. (Nasional \& NASIONAL, 2015).

Whereas according to (Paskarina, 2016), Indonesia has islands with strategic straits in its shipping. such as in Indonesian waters, namely the Malacca Strait, Lombok Strait, Sunda Strait, and Makassar Strait which are global maritime traffic. (Chen et al., 2014). The growth rate of the national shipping fleet market share is $46.4 \%$ for domestic transportation and $3.65 \%$ for foreign transportation. Growth The market share of sea transportation modes is also still low.

Whereas so far, $80-90 \%$ of Indonesia's export-import activities must go through ports in other countries (Putra \& Djalante, 2016). Therefore, the national transportation system should be arranged in an integrated manner and its effectiveness should be increased. (As, 2013).

The fact is that until now the maritime sector which has great potential has not been able to become the backbone of Indonesia's development and economy due to the lack of maritime contributions. Domestic products are only $\pm 4 \%$, much lower than other archipelagic countries in Asia, such as the Philippines (21\%) and Japan (28\%). The condition of infrastructure is still not balanced when compared to other archipelagic countries in Asia, for example, Japan, 3.6 islands/port and $340 \mathrm{~km} 2 /$ port; and the Philippines 10.1 islands/port and $460 \mathrm{~km} 2 /$ harbor. This is because the development program is partially carried out by the ministry and each institution, meaning that marine development has not been integrated and has not been concentrated (Kartika, 2016)

Several facts show that the national maritime sector still leaves several problems to be solved. First, ports have a big role in improving the national economy, but the existing conditions show that $66.96 \%$ of Indonesia does not yet have a port with a good governance system in the eyes of its users. One of the main indicators is the occupancy rate of mooring ships, the average turnover around time, and working time as a percentage of turn-around time are still below international standards and indicate that the ship is spending too much time at mooring. ships or queuing outside the port (PERTIWI, 2020). Second, based on the 2017 Bappenas report, the increasing role of Indonesian sea transportation has only reached $4 \%$ of all Indonesian transportation, where the portion is very small for an archipelagic country. Third, the position of Indonesia's Global Competitiveness Index (CGI), which is ranked 50th in the world, is still inferior to other countries in the ASEAN region.

In addition, the understanding of things that can improve or realize maritime security stability and national interests must be improved, this will have an impact on economic development, efforts to realize the sea area as the centrality of policy, and national welfare. (Nugraha \& Sudirman, 2016).

PT. Pelabuhan Indonesia III (Persero) or known as Pelindo III is one of the StateOwned Enterprises engaged in port services. Pelindo III runs its core business as a provider of port service facilities which has a key role to ensure the continuity and smoothness of sea transportation. PT Pelindo III (Persero), headquartered in Surabaya, manages 43 ports spread across seven provinces, namely East Java, Central Java, South Kalimantan, Central Kalimantan, Bali, West Nusa Tenggara, and East Nusa Tenggara, and has six subsidiaries. Of the seven provinces whose ports are managed by PT Pelindo III (Persero), this research focuses on PT.

PT. Pelabuhan Indonesia III (Persero) Banjarmasin Branch provides services to port service users, including ship scouting services and tugboat services, tugboats are used to provide services to ships that have a length of more than $70 \mathrm{~m}$ that carry out motion in waters where piloting is mandatory. , whether to anchor or leave the port, by holding, pushing, and pulling. Activities of providing port services by PT. Pelindo III (Persero) Banjarmasin Branch is quite good, among others: (1) in terms of interaction quality; Maritime pilots must be polite in serving customers, Pandu works professionally and has a fast response when customers need, (2) in terms of physical quality; PT. Pelabuhan Indonesia III Banjarmasin Branch already has an attractive building, up-to-date and wellfunctioning equipment, a clean environment, 
a spacious and comfortable waiting room, (3) in terms of product quality; Employees always optimize waiting times well and always give a good impression to all customers. However, there are still some services that are considered unfavorable, such as; There are still some ships that have not received good pilotage services, such as ships that experience delays in time to dock. However, this may be due to excessive transport capacity, the distance traveled, and the time required for the transport itself. (Februarianto, 2017) or some have left the port dock due to the unavailability of pilots who stand by at Taboneo Station and tugboats that work together with other ships, causing delays. Whereas according to previous research, service quality will have a positive and significant effect on customer satisfaction (Mulatsih, 2016); (Aryani \& Rosinta, 2011); (Darmanto, 2016)

Currently PT. Pelabuhan Indonesia III Banjarmasin Branch has 54 pilots and 2 tugboats. With this amount, it turns out that they have not been able to serve the ship on time. For this reason, the activities of providing port services by PT. Pelabuhan Indonesia III Banjarmasin Branch is required to be able to create customer satisfaction by providing maximum service. Based on customer surveys from 2018 - 2019 fluctuated with an increasing trend. The increasing number of complaints or complaints is an indication that consumers who use port services at PT. Pelabuhan Indonesia III (Persero) Banjarmasin Branch experienced service satisfaction problems.

The first factor is the problem of service satisfaction felt by consumers at PT. Pelabuhan Indonesia III (Persero) Banjarmasin Branch is a service quality that is still low by some unscrupulous pilots who often leave ships in the Taboneo area so that the ship experiences delays in docking at the Trisakti pier, container pier, Martapura pier, and Pertamina pier. And passenger ships often enter the Banjarmasin channel on their own (without a pilot) because there are no pilots at the Taboneo pilot station. Tugboats that pull coal barges often enter and leave without a guide on board, even though the Port Authority office allows without a guide, especially tugboats that pull coal barges. However, the company still feels uncomfortable when the ship enters and leaves without a guide on the ship. Therefore, the problem is the responsibility of the Pelindo III Banjarmasin Branch to be resolved immediately.

The second factor that causes customer satisfaction problems is tariffs. Each type of service available at the port (port pricing) is closely related to tariffs. Port service tariffs occur because there are parties who provide/provide services (by the port operator) so the tariff must be clear on the amount, type of service provided, and how it is enforced.

1. PT. Pelabuhan Indonesia III (Persero) Banjarmasin Branch seeks to attract customers by optimizing the tariff setting for scout services and improving the quality of ship scout services. Optimizing scouting service tariff settings which are of course proportional to the level of service and security of the services provided. Determination of competitive rates is done by changing the quality of service to the maximum, for example, there is no shipping delay which will have an impact on the high costs that must be incurred so that customers are satisfied with the services provided by PT. Pelabuhan Indonesia III Banjarmasin Branch so that there are no complaints felt by customers.

2. This study aims to determine the effect of tariffs and the quality of ship piloting services at PT. Indonesian Port III Banjarmasin Branch. This research is expected to provide consideration for the Company to develop service quality and tariff management at PT Pelabuhan Indonesia III Banjarmasin Branch.

The objectives of this research are

1. To analyze the effect of tariffs on customer satisfaction at PT. Pelabuhan Indonesia III (Persero) Banjarmasin Branch.

2. To analyze the effect of interaction quality on customer satisfaction at PT. Port of Indonesia III (Persero) Banjarmasin Branch.

3. To analyze the effect of the quality of the physical environment on customer satisfaction at PT. Pelabuhan Indonesia III (Persero) Banjarmasin Branch

4. To analyze the effect of quality results on customer satisfaction at PT. Pelabuhan Indonesia III (Persero) Banjarmasin Branch. 


\section{Research Methodology}

The type of research used in this research is quantitative research. (MONTEIRO, SULARSO, \& SUSANTO, n.d.) suggest that positivist researchers are used to examining certain populations or samples, sampling techniques are generally carried out randomly, data collection using research instruments, statistical quantitative data analysis to test predetermined hypotheses. Place This research was conducted at PT. Pelabuhan Indonesia III (Persero) Banjarmasin Branch. Research time was September 2019- March 2020. The population in this study are all customers/users of pilotage services at PT. Pelabuhan Indonesia III (Persero) Banjarmasin Branch with 115 customers.

\section{Method of collecting data}

The methods used are:

The questionnaire is a data collection technique by compiling a list of questions asked to respondents to get answers and responses and information needed by researchers. The list of questions is structured in the form of multiple-choice questions and open-ended questions using the google form.

\section{Definition of Variable Measurement}

Research variables can be divided into 2, namely:

\section{Independent Variable}

\section{a. Rates (X1).}

Tariff or price is an amount of money charged for an amount of the value exchanged by consumers for the benefits of having or using a product or service (Kotler in Meithiana (Arifianto \& Hasanudin, 2020)

The price indicators used

are as follows:

1) Price affordability

2) Price match with product quality

3) Price match with benefits

4) Price according to ability
5) Prices are in line with consumer expectations

b. Interaction Quality (X2).

The quality of interaction has been identified as face-to-face with consumers and employees (Brady \& Cronin Jr, 2001).

The Interaction Quality Indicators used adopted the research of (Alexandris, Zahariadis, Tsorbatzoudis, \& Grouios, 2004) as follows:

1) Polite employees

2) Employees value customer needs

3) Employees help customers to feel comfortable

4) Employees respond quickly

5) Employees give individual attention

6) Employees work enthusiastically

7) Knowledgeable employees

8) Reliable employees

9) Trusted employees

c. Physical Environment Quality (X3).

The quality of the physical environment refers to being tangible and involving customers during the process, the existence of the environment and its surroundings can have a significant influence on the overall perceived service quality (Alexandris et al., 2004).

Physical Environment Quality Indicators used adopted the research of (Alexandris et al., 2004) as follows:

1) Clean facilities

2) Equipment in good condition

3) Interesting facilities

4) Facilities have the latest equipment

5) Spacious facilities 
6) The facility has a nice atmosphere

7) Good experience

d. Quality of Results (X4).

The quality of the results is more on what factors are left by consumers when the service is provided. Where, what consumers leave behind are feelings or experiences experienced by consumers during the service process (Brady \& Cronin Jr, 2001).

The price indicators used are as follows:

1) Waiting time to get service can be estimated

2) Always strive for minimum waiting time

3) Understand the importance of waiting time for customers

4) Cooperative service

5) service as I expected

6) Understand the customer well

7) I have good memories with the services provided

8) Always trying to give the impression of good service

9) Knowing the type of service that customers want

\section{Dependent Variable}

Customer Satisfaction Variable

(Y). Customers will not be satisfied if

our performance fails to meet expectations and we can see that from the attitude of customers that arise and we can feel after getting the product they want. If performance matches expectations, customers will be satisfied. If the performance exceeds expectations, the customer will be very satisfied (Chandra, 2012).

The indicator of customer satisfaction used is adopted from the research of (Al-Hakim \& Hassan,
2013) in (Bagasworo, W., \& Rimadias, 2014) as follows:

1. Service received

2. Satisfying experience

3. Service provider

4. Options in using the service

5. Overall, satisfied with the service received

\section{Variable Measurement}

This study uses a Likert scale in the research instrument. The Likert scale is used to measure attitudes, opinions, and perceptions of a person or group of people about this social phenomenon that has been specifically determined by researchers hereinafter referred to as research variables (Monteiro et al.). This scale model is seen as follows:

- $\quad$ SS Strongly agree $=$ score 5

- $\quad$ S Agree $=$ Score 4

- $\quad$ RR Doubtful $=$ Score 3

- $\quad$ TS Disagree $=$ Score 2

$$
\text { - } \quad \text { STS Strongly disagree }=\text { Score } 1
$$

\section{Data Analysis Technique}

The tools used in this study are as follows:

1. Validity test

To find out the level of ability of an instrument, it can be shown by Validity.

2. Reliability Test

Reliability shows the extent to which an instrument can provide consistent measurement results. Reliability testing was carried out using the Cronbach Alpha Test with the following test results criteria (Pulungan \& Siregar, 2016)

3. Outlier Test

Outlier Data Outliers are cases or data that have unique characteristics that look very different from other observations and appear in the form of extreme values for either a single variable or a combination (Pulungan \& Siregar, 2016).

4. Classic assumption test

A classical assumption test is a test conducted to analyze the basic 
assumptions that must be met in the use of regression. This classical assumption test aims to produce the best unbiased linear estimator from the regression model obtained from the least-squares method. With the fulfillment of these assumptions, the results obtained can be more accurate and close to or equal to reality (Al-Hakim \& Hassan, 2013).

5. Linearity Test

Linearity test is used to determine whether the two variables that will be subjected to correlational statistical analysis procedures show a linear relationship or not

6. Multiple Regression Test

Multiple regression analysis is an analysis conducted to measure the strength of the relationship between 2 or more independent variables on the dependent variable. The formula used in the multiple regression analysis methods is as follows (Monteiro et al.) :

$Y=a+\beta_{1} X 1+\beta_{2} X 2+\beta_{3} X 3+\beta_{4} X 4+$

e1

Information:

\begin{tabular}{|c|c|c|}
\hline $\begin{array}{l}\text { Y } \\
\text { satisfaction }\end{array}$ & $=$ & Customer \\
\hline$a$ & \multicolumn{2}{|c|}{$=$ constant } \\
\hline $\mathrm{X} 1$ & \multicolumn{2}{|l|}{$=$ Tariff } \\
\hline $\mathrm{X} 2$ & $=$ & Interaction \\
\hline \multicolumn{3}{|l|}{ Quality } \\
\hline $\mathrm{X3}$ & $=$ & Physical \\
\hline \multicolumn{3}{|c|}{ Environment Quality } \\
\hline$X 4$ & \multicolumn{2}{|c|}{$=$ Yield Quality } \\
\hline $\begin{array}{l}\beta_{1}, \beta_{2}, \beta_{3}, \beta_{4} \\
\text { Coefficient }\end{array}$ & $=$ & Regression \\
\hline e & $=$ Error & \\
\hline
\end{tabular}

7. Hypothesis testing

Hypothesis testing used $F$ test statistic and T-test. $F$ test in this study simultaneous hypothesis testing is intended to measure the influence of independent variables, namely, Product Quality (X1), Price (X2), and Service Quality (X3) simultaneously (together). on the dependent variable, namely User Satisfaction $(Y)$, while the t-test is used to test the effect of each independent variable, the variable Product Quality (X1), Price (X2), and Service Quality (X3) have a partial (separate) effect on the dependent variable, namely User Satisfaction (Y).

8. Coefficient of Determination ( $R$ )

The coefficient of determination ( $r$ ) is used to measure the relationship between the independent variable and the dependent variable simultaneously or partially, while the coefficient of determination is a value that describes how much change or variation in the dependent variable can be explained by changes or variations in the independent variable.

\section{Respondent Description}

Respondents in this study are company leaders who have used ship scouting services at PT. Port of Indonesia III Banjarmasin Branch, totaling 115 customers. Based on gender, all respondents in this study were male or $100 \%$. Based on the age obtained, in general, the respondents were in the 3540 years age group, namely 37 respondents or $32.2 \%$. The age of the respondents in this study was 35-52 years old. Therefore, it can be said that in general, the respondents are still of productive age. Based on the education obtained in general, the respondents are with a bachelor's level of education as many as 70 respondents or $60.9 \%$. The respondents with a master's level of education were 45 respondents or $39.1 \%$. Based on the position obtained, in general, the respondents were with 
the position of operational manager as many as 96 respondents or $83.5 \%$. The respondents with manager positions were 19 respondents or $16.5 \%$.

\section{Validity Test and Reliability Test}

The validity test aims to determine whether the instrument used to measure behavior and impression assessment is appropriate or not. The instrument is said to be valid if $r$ count $>r$ table and significance $<0.05$, then the statement from the questionnaire is declared valid. The reliability test aims to determine the consistency of the measuring instrument. Reliability measurement is done by comparing the Cronbach Alpha numbers (Cronbach Alpha $>0.60$ ), so the questionnaire is declared reliable. The results of the validity and reliability tests in this study obtained that all items from X1.1 to Y5 were valid and reliable. So it can be interpreted that the instrument used to measure the variable is reliable.

\section{Classic Assumption Test}

\section{Normality test}

Table 1 Normality Test Results

\begin{tabular}{ccc|}
\hline Z count & Significance & Information \\
\hline 0.055 & 0.200 & Normal Distribution \\
\hline \multicolumn{2}{c}{ Source: Primary data processed }
\end{tabular}

Based on the results above, if the Kolmogorov significance value is above 0.05 then the data is normally distributed. And the value above is 0.200 and it means that the data in this study is normally distributed.

\section{Multicollinearity Test}

Table 2

Multicollinearity Test Results

\begin{tabular}{llll}
\hline Variable & Tolerance & VIEW & Information \\
\hline Tariff (X1) & 0.907 & 1,102 & $\begin{array}{l}\text { Non } \\
\text { Multicollinearity }\end{array}$ \\
\hline $\begin{array}{l}\text { Interaction } \\
\text { Quality (X2) }\end{array}$ & 0.850 & 1,176 & Non \\
\hline $\begin{array}{l}\text { Physical } \\
\text { Environment } \\
\text { Quality (X3) }\end{array}$ & 0.898 & 1.114 & Non \\
Qulicollinearity \\
\hline
\end{tabular}

\begin{tabular}{llll}
\hline $\begin{array}{l}\text { Result } \\
\text { Quality (X4) }\end{array}$ & 0.787 & 1,271 & Non \\
& & Multicollinearity \\
\hline
\end{tabular}

Source: Primary data processed

From the results above, we can see that there is no high relationship between the independent variables because each tolerance value is above 0.1 and the VIF is below 10 .

\section{Heteroscedasticity Test}

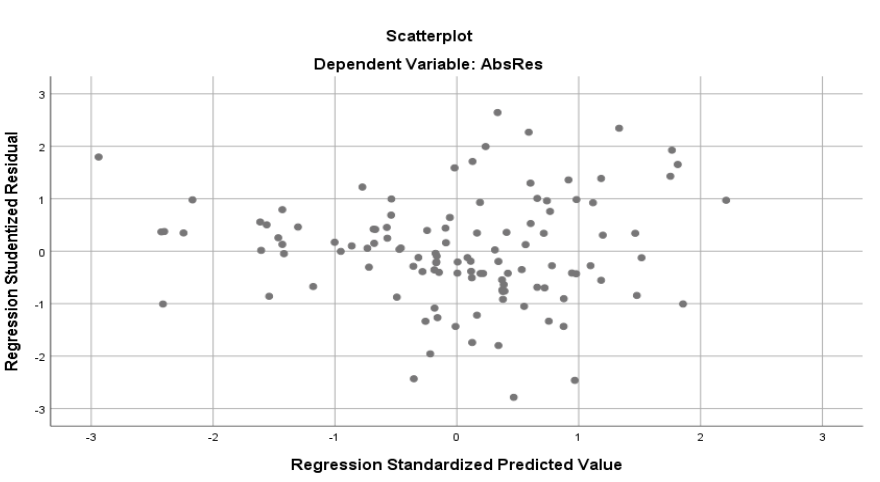

points or plots of data spread above and below the number 0 on the $\mathrm{Y}$-axis so that based on the graph, the regression model in this study does not occur heteroscedasticity.

\section{Linearity Test}

\section{Table 3}

Linearity Test Results

Source: Primary data processed

\begin{tabular}{llc}
\multicolumn{1}{c}{ Variable } & Sig. & Information \\
\hline Tariff $(X 1)$ & 0.190 & Linear \\
\hline h Interaction & 0.658 & Linear \\
e Quality $(X 2)$ & & \\
$\begin{array}{l}\text { Physical } \\
\text { Environment }\end{array}$ & 0.594 & Linear \\
a $\begin{array}{l}\text { Quality (X3) } \\
\text { b Result }\end{array}$ & 0.183 & Linear \\
o Quality (X4) & & \\
\hline$v$ & &
\end{tabular}

e results obtained that the significance value for all variables was above 0.05 so that the independent variable was linear to the dependent variable. 
Multiple Regression Test

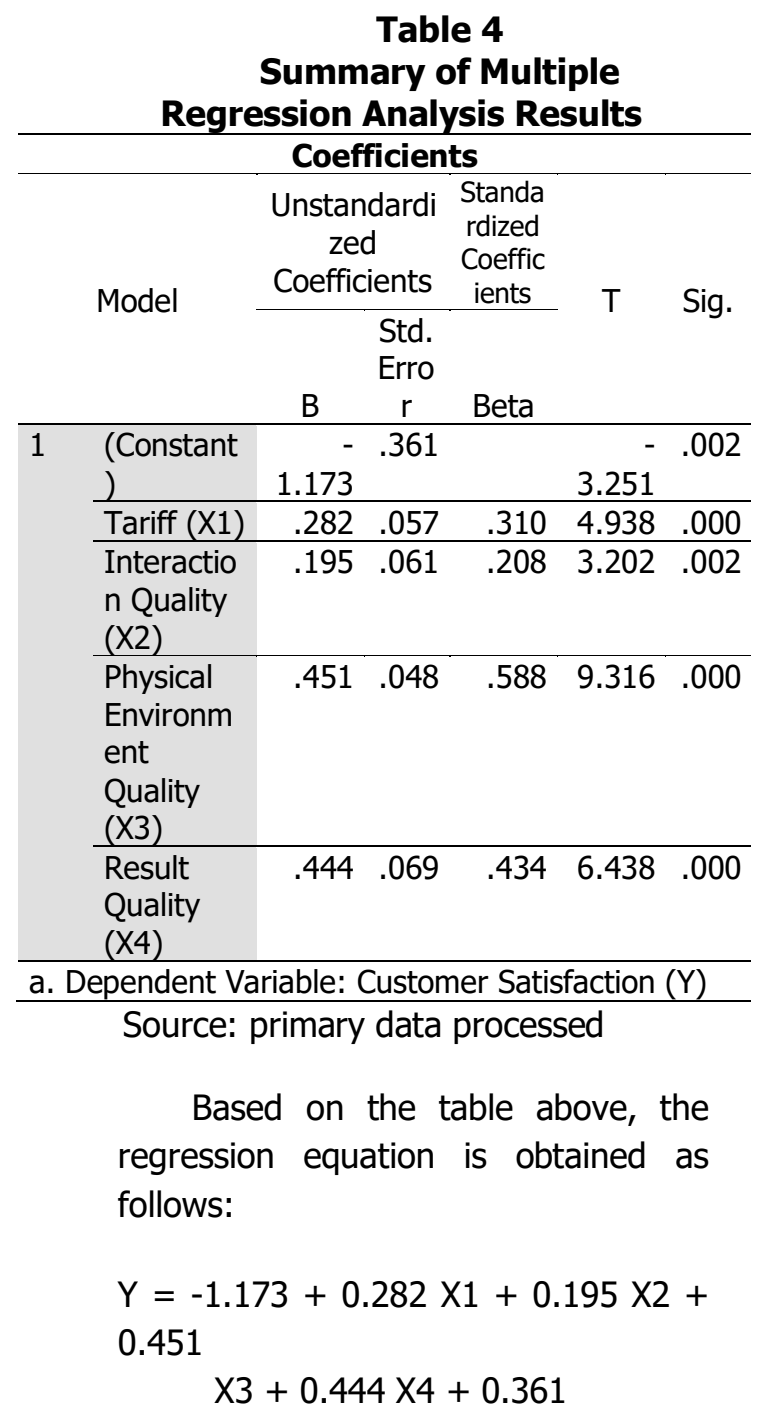

The interpretation of the multiple linear regression equation is:

a. The constant of -1.173 indicates a constant decrease from the customer satisfaction variable which is 1.173 regardless of the value of the independent variable. Therefore, increasing customer satisfaction can maximize the value of the independent variable.

b. The regression coefficient for the tariff variable $(\mathrm{X} 1)$ is 0.282 , meaning that if the other independent variable is fixed and the tariff (X1) has an additional value of 1 , then customer satisfaction $(Y)$ will increase by 0.282. The positive coefficient means that there is a positive relationship between customer satisfaction and tariffs, so if the rates provided are by the services received by customers, customer satisfaction will also increase. Conversely, if the rates provided are not by the services received, customer satisfaction will decrease or be dissatisfied.

c. The regression coefficient of the interaction quality variable (X2) is 0.195 , meaning that if the other independent variables are assumed to have a fixed value and the interaction quality (X2) has an additional value of 1 , then customer satisfaction $(Y)$ will increase by 0.195. The positive coefficient means that there is a positive relationship between customer satisfaction and the quality of the interaction, the better the quality of the interaction provided, the more customer satisfaction will increase.

d. The regression coefficient for the physical environment quality variable $(\mathrm{X} 3)$ is 0.451 , meaning that if the other independent variables are assumed to have a fixed value and the physical environment quality (X3) has an additional value of 1 , then the customer satisfaction $(Y)$ will increase by 0.451 . The positive coefficient means that there is a positive relationship between customer satisfaction and the quality of the physical environment, the better the quality of the physical environment provided, the more customer satisfaction will increase.

e. The regression coefficient of the result quality variable $(\mathrm{X} 3)$ is 0.444 , meaning that if the other independent variables are assumed 
to have a fixed value and the resulting quality (X3) has an additional value of 1 , then customer satisfaction $(Y)$ will increase by 0.444 . The positive coefficient means that there is a positive relationship between customer satisfaction and the quality of the results, the better the quality of the results provided, the more customer satisfaction will increase.

\section{Hypothesis}

\section{Partially Test Results}

a. The tariff variable has an at-count value of 4.938 and a significance of 0.000 so that the significance value is less than 0.05 , so there is a partially significant effect of the tariff variable on customer satisfaction. The regression coefficient value of 0.282 indicates a positive influence, meaning that the more appropriate the tariff, the customer satisfaction will also increase and vice versa. This coefficient value also means that customer satisfaction will increase by 0.282 units for every one-unit increase in tariffs

b. The interaction quality variable has an at-count value of 3.202 and a significance of 0.002 so that the significance value is less than 0.05 , so there is a partially significant effect of the interaction quality variable on customer satisfaction. The regression coefficient value of 0.195 indicates a positive influence, meaning that the better the quality of the interaction, the more customer satisfaction will also increase and vice versa. This coefficient value also means that customer satisfaction will increase by 0.195 units for every one-unit increase in interaction quality c. The physical environment quality variable has an at-count value of 9.316 and a significance of 0.000 so that the significance value is less than 0.05 , so there is a partially significant effect of the physical environment quality variable on customer satisfaction. The regression coefficient value of 0.451 indicates a positive influence, meaning that the better the quality of the physical environment, the more customer satisfaction will also increase and vice versa. This coefficient value also means that customer satisfaction will increase by 0.451 units for every one-unit increase in the quality of the physical environment

d. The result quality variable has an at-count value of 6.438 and a significance of 0.000 so that the significance value is less than 0.05 , so there is a partially significant effect of the result quality variable on customer satisfaction. The regression coefficient value of 0.444 indicates a positive influence, meaning that the better the quality of the results, the more customer satisfaction will also increase and vice versa. This coefficient value also means that customer satisfaction will increase by 0.444 units for every one-unit increase in the quality of results

\section{Simultaneous Test Results} Table 5

\begin{tabular}{lll}
\hline $\mathbf{F}$ & Sig. & Information \\
Statistics & & \\
\hline 42,374 & 0.000 & Significant \\
\hline
\end{tabular}

Source: Primary data processed

There is a joint influence between independent variables if the calculated $F$ value is greater than the $\mathrm{F}$ table and the significance 
is less than 0.05 . The Fount value is 42,374 and the significance is 0.000 so that the calculated $F$ value is greater than the $\mathrm{F}$ table and the significance is less than 0.05 , it can be concluded that there is a simultaneous effect of a variable tariff, interaction quality, physical environment quality, and result quality on customer satisfaction.

3. Coefficient of Determination Test Results

\begin{tabular}{ccc}
\multicolumn{3}{c}{ Table 6 } \\
\hline $\mathbf{R}$ & $\begin{array}{c}\mathbf{R} \\
\text { Square }\end{array}$ & Information \\
\hline 0.779 & $\mathbf{0 . 6 0 6}$ & $\begin{array}{c}\text { Independent variable } \\
\text { Capable explain 60.6\% }\end{array}$
\end{tabular}

Source: Primary data processed

The correlation value is 0.779 which shows the magnitude of the joint relationship of a variable rate, the quality of interaction, the quality of the physical environment, and the quality of results on customer satisfaction. This value if squared will produce an $\mathrm{R}$ square value of 0.606 . The coefficient of determination aims to determine the magnitude of the influence of the independent variable on the dependent variable. The result of the coefficient of determination above is 0.606 which can be said to be variable rates, interaction quality, physical environment quality, and output quality able to influence customer satisfaction as big as $60.6 \%$ while the rest is influenced by other variables that are not the focus of this study.

\section{DISCUSSION}

1. The Effect of Physical Environment Quality Variables on Customer Satisfaction at PT. Pelabuhan Indonesia III (Persero) Banjarmasin Branch

The results of hypothesis testing

$\mathrm{H} 2$ show that the variable of the quality of the physical environment has a positive and significant effect on customer satisfaction at PT. Indonesian Port III Banjarmasin. This means that service users are very concerned with the quality of services provided by service providers. Therefore, to ensure that customer satisfaction can be realized, one of the efforts that must be made by the company is to ensure that the quality of the physical environment remains good. For example, by maintaining cleanliness, comfort, temperature, waiting room and maintaining an attractive interior and exterior design and always keeping the equipment in good condition and functioning properly so as not to interfere with operations while the service is in progress. The results of this study strengthen the previous research by Alexandris et al. (2013).

2. The Effect of Variable Quality Results Influences on Customer Satisfaction at PT. Pelabuhan Indonesia III (Persero) Banjarmasin Branch

The results of hypothesis testing $\mathrm{H} 4$ show that the variable quality of results has a positive and significant effect on customer satisfaction at PT. Indonesian Port III Banjarmasin. This means that service users are very concerned with the quality of services provided by service providers. Therefore, to ensure that customer satisfaction can be realized, one of the efforts that can be made by the company is to ensure that the quality of the results remains good. for example, by keeping no waiting time for customers, always providing good service so that it will have an impact on good impressions and memories to customers. The results of this study strengthen the previous research by Hussain et al. (2015). This study show effort that the quality of the results has a significant effect on customer satisfaction. 
3. The Effect of Vessel Guiding Tariff Variables on Customer Satisfaction at PT. Pelabuhan Indonesia III (Persero) Banjarmasin Branch.

The results of hypothesis testing $\mathrm{H} 1$ show that the tariff variable has a positive and significant effect on customer satisfaction at PT. Indonesian Port III Banjarmasin. This means that service users are very concerned with the rates set by the service provider. The results of this study strengthen the previous research by (Ariani, Firdaus, \& Hairudinor, 2019). The research

shows that tariffs have a significant effect on customer satisfaction.

4. The Effect of Interaction Quality Variables on Customer Satisfaction at PT. Pelabuhan Indonesia III (Persero) Banjarmasin Branch.

The result of hypothesis testing $\mathrm{H} 2$ shows that the interaction quality variable has a positive and significant at PT. Pelabuhan Indonesia III (Persero) Banjarmasin Branch. This means that service users are very concerned with the quality of service provide by service providers. Therefore, to ensure that customer satisfaction can be realized, one of the efforts that must be made by the company is to ensure that the quality of interaction remains good, for example from the attitude, always being polite when serving all customers, respecting customers, helping customers to make customers feel comfortable. Form behavior, responding quakily to what customers need and always paying attention to customers, and always providing the best service to all customers. From expertise, giving thrust to all customers with extensive and reliable knowledge in providing ship piloting services. The results of this study strengthen the previous research by Murbani et al. (2014)

\section{CONCLUSION}

The conclusion of this research is as follows: 1). Variable ship pilotage rates affect customer satisfaction at PT. Pelabuhan Indonesia III (Persero) Banjarmasin Branch, 2).The interaction quality variable has an effect on customer satisfaction at PT. Pelabuhan Indonesia III (Persero) Banjarmasin Branch,3).Physical Environment Quality Variables have an effect on customer satisfaction at PT. Pelabuhan Indonesia III (Persero) Banjarmasin Branch The resulting quality variable has an effect on customer satisfaction at PT. Pelabuhan Indonesia III (Persero) Banjarmasin Branch.,4). The result quality variable has an effect on customer satisfaction at PT. Pelabuhan Indonesia III (Persero) Banjarmasin Branch.

\section{REFERENCES}

Adisasmita, Sakti Adji. (2011). Perencanaan Pembangunan Transportasi. Graha Ilmu.Google Scholar

Al-Hakim, Laith Ali Yousif, \& Hassan, Shahizan. (2013). Knowledge Management Strategies, Innovation, And Organizational Performance: An Empirical Study Of The Iraqi Mts. Journal Of Advances In Management Research. Google Scholar

Alexandris, Konstantinos, Zahariadis, Panagiotis, Tsorbatzoudis, Charalambos, \& Grouios, George. (2004). An Empirical Investigation Of The Relationships Among Service Quality, Customer Satisfaction, And Psychological Commitment In A Health Club Context. European Sport Management Quarterly, 4(1), 36-52. Google Scholar

Ariani, Sisca, Firdaus, Muhammad Riza, \& Hairudinor, H. (2019). Analysis Of The 
Influence Of Service Quality, Price, Trust And Corporate Image On Satisfaction And Customer Loyalty In Pt. Pos Indonesia Banjarmasin. European Journal Of Management And Marketing Studies. Google Scholar

Arifianto, Chandra Fitra, \& Hasanudin, Moh Hatta. (2020). Pengaruh Kualitas Layanan Yang Diterima Daring (Pesq) Terhadap E-Satisfaction Yang Dimediasi Oleh Kepercayaan Daring Atas Layanan Daring Pada Implementasi E-Spm. Indonesian Treasury Review: Jurnal Perbendaharaan, Keuangan Negara Dan Kebijakan Publik, 5(4), 243-354. Google Scholar

Aryani, Dwi, \& Rosinta, Febrina. (2011). Pengaruh Kualitas Layanan Terhadap Kepuasan Pelanggan Dalam Membentuk Loyalitas Pelanggan. Bisnis \& Birokrasi: Jurnal Ilmu Administrasi Dan Organisasi, 17(2). Google Scholar

As, Nursyam. (2013). Struktur Tata Ruang Wilayah Dan Kota. Google Scholar

Bagasworo, W., \& Rimadias, S. (2014). Increasing Student Satisfaction Through Qualityjassaeducation. Journal Of Management \& Economics. 7(2). Google Scholar

Brady, Michael K., \& Cronin Jr, J. Joseph. (2001). Some New Thoughts On Conceptualizing Perceived Service Quality: A Hierarchical Approach. Journal Of Marketing, 65(3), 34-49. Google Scholar

Chandra, Fenita. (2012). Peranan Strategi Penetapan Harga Untuk Meningkatkan Penjualan Ritel. Kajian Ilmiah Mahasiswa Manajemen, 1(2). Google Scholar

Chen, Jonathan, Gleason, Andrea, NabbsKeller, Greta, Sambhi, Natalie, Springer, Kyle, \& Tanu, Danau. (2014). New Perspectives On Indonesia: Understanding Australia's Closest Asian Neighbour. Perth Usasia Centre. Google Scholar
Darmanto, Susetyo. (2016). Analisis Pengaruh Kualitas Layanan Dan Fasilitas Ekspor Terhadap Kepuasan Dan Loyalitas Pelnggan Jasa Containership Regional Container Line (Rcl) Semarang. Media Ekonomi Dan Manajemen, 24(2). Google Scholar

Februarianto, Rezki. (2017). Tanggung Jawab Maskapai Lion Air Terhadap Keterlambatan Jadwal Penerbangan Di Bandara International Minangkabau. Abstract Of Undergraduate Research, Faculty Of Law, Bung Hatta University, 8(1). Google Scholar

Gindarsah, Lis. (2014). Politics, Security, And Defense In Indonesia: Interactions And Interdependencies. National Security College. Google Scholar

Kartika, Shanti Dwi. (2016). Keamanan Maritim Dari Aspek Regulasi Dan Penegakan Hukum (Maritime Security From The Aspects Of Regulation And Law Enforcement). Negara Hukum: Membangun Hukum Untuk Keadilan Dan Kesejahteraan, 5(2), 143-167. Google Scholar

Kusuma, Nunuk Widyawati, Setiono, Benny Agus, \& Poli, Sofyan. (2018). Pengaruh Kualitas Pelayanan Jasa Pemanduan Terhadap Kepuasan Pelanggan Di Pt Pelabuhan Indonesia Iii (Persero) Cabang Tanjung Perak Surabaya. Jurnal Aplikasi Pelayaran Dan Kepelabuhanan, 6(1), 41-51. Google Scholar

Monteiro, Mualim, Sularso, Raden Andi, \& Susanto, Arnis Budi. (N.D.). The Influence Of Leadership Style And Work Discipline On Employee Performance With Work Motivation At Pt. Toyota Auto 2000 Jember Branch. Google Scholer

Mulatsih, Retno. (2016). Studi Kepuasan Penumpang Kereta Api Kamandaka Jurusan Semarang-Purwokerto. Jurnal Dinamika Ekonomi \& Bisnis, 13(2). Google Scholar

Nasional, Kementerian Perencanaan 
Pembangunan, \& Nasional, Badan Perencanaan Pembangunan. (2015). Pengembangan Tol Laut Dalam Rpjmn 2015-2019 Dan Implementasi 2015. B. Prihartono, Jakarta. Google Scholar

Nugraha, Muhammad Harry Riana, \& Sudirman, Arfin. (2016). Maritime Diplomacy Sebagai Strategi Pembangunan Keamanan Maritim Indonesia. Jwp (Jurnal Wacana Politik), 1(2). Google Scholar

Paskarina, Caroline. (2016). Wacana Negara Maritim Dan Reimajinasi Nasionalisme Indonesia. Jurnal Wacana Politik, 1(1), 1-8. Google Scholar

Pertiwi, Gustina Fatma. (2020). Pengaruh Kedisiplinan Dan Motivasi Belajar Siswa Saat Pandemi Covid-19 Terhadap Hasil Belajar Ilmu Pengetahuan Alam Pada Siswa Kelas Viii Smp Negeri 2 Getasan Tahun Pelajaran 2019/2020. Google Scholar
Pulungan, Muhammad Sadat Husein, \& Siregar, Nolita Yeni. (2016). Emotional Intelligence, Spiritual, Intellectual And Conduct Study On The Level Of Understanding Of Accounting (Empirical Study Of Accounting Students In Colleges In Lampung). International Conference On Information Technology And Business (Icitb), 28-34. Google Scholar

Putra, Adris A., \& Djalante, Susanti. (2016). Pengembangan Infrastruktur Pelabuhan Dalam Mendukung Pembangunan Berkelanjutan. Jurnal Ilmiah Media Engineering, 6(1). Google Scholar

Sinaga, Mithun, Mamahit, D. A., \& Yusnaldi, Yusnaldi. (2020). Pembangunan Infrastruktur Maritim Untuk Mendukung Program Tol Laut Dalam Mewujudkan Poros Maritim Dunia (Pmd). Keamanan Maritim, 6(1). Google Scholar

\section{Copyright holder:}

Mawan Budiyanto, RR Yulianti Prihatiningrum (2021)

First publication right:

Journal of Social Science

This article is licensed under:

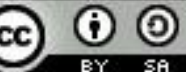

